\title{
Conjugation of Au Nanoparticles with Chlorambucil for Improved Anticancer Activity
}

\author{
I. S. Vijayashree ${ }^{1}$ - P. Niranjana ${ }^{1}$ G. Prabhu ${ }^{2}$. \\ V. V. Sureshbabu ${ }^{2} \cdot$ J. Manjanna ${ }^{3}$
}

\begin{abstract}
Gold nanoparticles (AuNPs) of 30-40 nm in size has been prepared using A. hirsutus leaves extract as reducing agent for $\mathrm{Au}^{3+}$ ions under microwave irradiation from 60 to $360 \mathrm{~s}$. These biocapped AuNPs were effectively conjugated with activated folic acid (FA, receptor) and chlorambucil (CHL, anticancer drug) molecules. The formation of AuNPs-FA-CHL was confirmed from different characterization techniques such as XRD, UV-Visible spectra, FT-IR and TEM images. The anticancer activity of these bioconjugated AuNPs was tested against human cancer cell lines (HeLa, RKO and A549) in comparison with normal epithelial cells (Vero). Unlike AuNPs and CHL alone, AuNPs-FA-CHL showed high toxicity towards human cancer cells by significantly decreasing the percentage viability of cells. Furthermore, the amount of drug released was found to be maximum at an ideal tumor environment $\mathrm{pH}$ 5.3.
\end{abstract}

Keywords A. hirsutus extract - Microwave irradiation - Gold nanoparticles · Bioconjugation · Anticancer activity

P. Niranjana

bpniru@gmail.com

J. Manjanna

jmanjanna@rediffmail.com

1 Department of Biochemistry, Kuvempu University, Shankaraghatta 577451, India

2 Department of Chemistry, Central College Campus, Bangalore University, Bangalore 560 001, India

3 Department of Chemistry, Rani Channamma University, Belagavi 591 156, India 


\section{Introduction}

Conventionally different types of chemotherapeutic agents [1,2] are used for the treatment of cancer for a very long period. High doses of these drugs not only invade the affected sites but freely move through the circulatory system, affecting various parts of the body causing major side effects viz., nausea, vomiting, anemia, decreased appetite, nail discoloration, renal failure etc. The intrinsic toxicity of classical anticancer drugs, and their lack of accessibility at the tumor site, reduced intake and rapid elimination of drugs by tumor cells are the major difficulties associated with treating several types of cancer [3].

Some polymeric micelles and dendrimers are known to significantly increase the rate of delivery of hydrophobic drugs at the target site [4, 5]. However, they are found to have some of limitations, for example, limited drug loading capacity. Therefore innovative nanodevices and nanostructures are being developed for effective anticancer treatment. Particularly, AuNPs are used due to their biocompatibility, easy preparation and their ability to bind with various biomolecules (receptors and drugs). AuNPs are used for bio-imaging, targeted drug delivery and photodynamic therapy due to their localized surface plasmon resonance. The AuNPs have shown increased binding affinity and selectivity when functionalized with various biomolecules such as antibiotics, proteins, receptors, drugs etc., which helps in precise targeting of drug to the tumor site $[6,7]$.

The AuNPs synthesized using plant extracts [8, 9], fungus [10] etc. have numerous benefits. These AuNPs are biocompatible and highly stable at physiological conditions and are protected/capped by biomolecules/peptides which acts as natural linkers for drugs, antibodies etc. Jang et al. [11] have shown effective and sustained delivery of doxorubicin from dextran-coated AuNPs to HeLa cell lines. Tomuleasa et al. [12] have synthesized AuNPs-L-aspartate nanostructure and then non-covalently conjugated to cisplatin and capecitabine. These particles are found to reduce cellular proliferation rate in hepatocellular carcinoma (HCC). Gibson et al. [13] have synthesized $2 \mathrm{~nm}$ AuNPs covalently attached to chemotherapeutic drug paclitaxel. It is well known that, $\mathrm{CHL}$ is one of the important chemotherapeutic drugs used for the treatment of cancer. It is an alkylating agent which reduces the cell proliferation by inhibiting the DNA replication [14]. The folic acid (FA) is used as a navigational molecule attached to drug [15]. FA conjugated NPs have been found to target cancer cells, which over express folate receptors on their surfaces due to their huge requirement for FA. Conjugation of nanoparticles with FA will result in effective targeting of NPs leading to synaptic and controlled release of drug at tumor site, which reduces its adverse effect on nearby healthy cells. Later these NPs can enter cell via receptor mediated endocytosis [16]. There are many reports where CHL is used as an effective anti-cancer drug; but has failed as active targeting at the tumor site $[17,18]$. Hence, this study has focused on the formation of AuNPs-FA-CHL complex as active targeted cancer agent; which minimizes the amount of drug required for treatment of cancer; and also reduces the adverse effect on the healthy cell. In this study, we report the formation of AuNPs using $A$. hirsutus leaves extract as reducing agent. These NPs are conjugated with FA as 
linking/anchoring molecule and CHL drug. The anticancer activity of these nanovehicles is studied against different cell lines.

\section{Materials and Methods}

\section{Materials}

Gold aurochlorate, dimethyl sulfoxide (DMSO) and propanol were obtained from Merck Chemicals Ltd., Mumbai, India. CHL, FA, 3-(4,5-dimethyl thiazol-2-yl)-5diphenyl tetrazolium bromide (MTT), fetal bovine serum (FBS), phosphate buffered saline (PBS), Dulbecco's modified eagle's medium (DMEM) and trypsin were obtained from Sigma Aldrich Co, St Louis, USA. EDTA, glucose and antibiotics were from Hi-Media Laboratories Ltd., Mumbai, India. The normal (Vero) and cancer cell lines viz., HeLa, RKO and A549 were procured from National Centre for Cell Sciences (NCCS) Pune, India. All the experiments were carried out using distilled water.

\section{Preparation of Aqueous A. hirsutus Leaves Extract}

A. hirsutus plant (available in Western ghat region of Karnataka) leaves were collected and cleaned using distilled water and cut into small pieces. A $10 \mathrm{~g}$ of these leaves were soaked in $200 \mathrm{ml}$ of distilled water and kept for microwave irradiation (ONIDA, $2.45 \mathrm{GHz}$ ) for about $180 \mathrm{~s}$ to extract the biomolecules present in the leaves. The fibrous impurities were filtered in hot condition using $0.2 \mu \mathrm{m}$ membrane filter paper and stored at $4{ }^{\circ} \mathrm{C}$ for further experimental requirements.

\section{Synthesis of AuNPs}

A $10 \mathrm{ml}$ of leaves extract was added to $50 \mathrm{ml}$ of $1 \mathrm{mM} \mathrm{HAuCl}_{4}$ and the mixture was microwave irradiated at a fixed frequency of $2.45 \mathrm{GHz}$ at regular intervals of time (the experiment was done in duplicate for reproducibility). As the reaction proceeds, the reaction mixture changed to light yellow and then to dark brown indicating the formation of AuNPs, and it was recorded periodically using UV-Vis spectrum (Shimadzu, 1650-PC) to observe the surface plasmon resonance peak. After about $360 \mathrm{~s}$, there was no further increase in the absorption peak and also any change in color. The colloidal solution thus obtained was centrifuged at $10,000 \mathrm{rpm}$ for $15 \mathrm{~min}$ and washed several times with distilled water. The AuNPs were dried in vacuum oven at $80{ }^{\circ} \mathrm{C}$ for about $12 \mathrm{~h}$ to obtain the product in powdered form for further studies.

\section{Conjugation of Activated FA and CHL to AuNPs}

FA (0.25 g) was dissolved in DMSO using sonicator. To this solution, n-hydroxy succinimide (NHS, $0.225 \mathrm{~g}$ ) and dicarboxy aminocarbodiimide (DCC, $0.125 \mathrm{~g}$ ) were added (FA/NHS/DCC molar ratio 2:2:1) [19]. It was stirred continuously for 
about $12 \mathrm{~h}$ in an argon atmosphere at room temperature (RT). The activated FA in the form of colloidal mixture was collected by filtration. It was dried at RT. A $0.1 \mathrm{~g}$ of this powder and $500 \mathrm{mg}$ of AuNPs were added to $20 \mathrm{ml}$ of DMSO and stirred continuously for about $30 \mathrm{~h}$ under argon atmosphere to obtain AuNPs-FA complex. This complex was collected by filtration and dried at RT. Further, equimolar amounts of CHL (0.25 mM) and AuNPs-FA (0.25 mM) treated with using N N'carbonyldiimidazole (CDI) in presence of imidazole hydrochloric acid. The molar ratio of AuNPs-FA/CHL/CDI was 1:1:2. The mixture was stirred continuously at RT for about $24 \mathrm{~h}$. The resultant AuNPs-FA-CHL conjugate was subjected for dialysis for $24 \mathrm{~h}$ to remove the excess reactants.

\section{Drug Releasing Studies}

Amount of drug released was studied by adding $5 \mathrm{ml}$ of AuNPs-FA-CHL complex to three different porous dialysis tubes which were placed separately in a beaker containing $50 \mathrm{ml}$ of phosphate buffer solution maintained at different $\mathrm{pH}(5.3,6.8$ and 7.2) and was continuously stirred at $100 \mathrm{rpm}$. The entire system was kept in an incubator at $37^{\circ} \mathrm{C}$. To measure the drug release content, $1 \mathrm{ml}$ samples were periodically removed and replaced with an equivalent volume of phosphate buffer solution. The amount of drug released was monitored by recording UV-Vis spectrophotometer at $485 \mathrm{~nm}$. The experiments were done in triplicate and mean $(\bar{X})$ values were calculated.

\section{Characterization Techniques}

The X-ray diffraction (XRD) pattern of AuNPs was recorded by Siemens X-ray diffractometer, Japan with $\mathrm{Cu} \mathrm{K} \alpha$ radiation $(\mathrm{k}=0.15406 \mathrm{~nm})$ at a scanning rate of $2 \%$ min and $2 \theta$ ranging from 30 to $80^{\circ}$. Transmission electron microscopy (TEM, PHILIPS CM-200) was used to observe the morphology of AuNPs. Fourier transform infrared (FT-IR, Bruker-TENSOR 27) spectra were recorded in $\mathrm{KBr}$ pellet to known the type of phytochemicals adsorbed/anchored on the surface of AuNPs with activated FA and anticancer drug.

\section{Cytotoxicity Studies}

The cytotoxic effect of AuNPs, CHL and AuNPs-FA-CHL conjugate were tested against HeLa, RKO and A549 cells by MTT assay. The principle involved is the cleavage of tetrazolium salt of MTT into a blue colored product (formazan) by mitochondrial enzyme succinate dehydrogenase [20]. The assay depends both on the number of cells present and on the mitochondrial activity per cell, as the dead cells or their products do not reduce tetrazolium.

For preparation of test solutions, the weighed samples viz., AuNPs, CHL, AuNPs-FA and AuNPs-FA-CHL were dissolved in DMSO to obtain different doses levels, $0-250 \mathrm{mg} / \mathrm{ml}$. To each well of the 96 well microtitre plate, $0.1 \mathrm{ml}$ of the diluted cancer cell suspension (approximately 10,000 cells) was added. After 
$24 \mathrm{~h}, 100 \mu \mathrm{l}$ of test samples were added to the microtitre plates. The plates were then incubated at $37^{\circ} \mathrm{C}$ for 3 days in $5 \% \mathrm{CO}_{2}$ atmosphere. After $72 \mathrm{~h}$, the drug solutions in the wells were discarded and $50 \mu \mathrm{l}$ of MTT in PBS was added to each well. The plates were gently shaken and incubated for $3 \mathrm{~h}$ at $37^{\circ} \mathrm{C}$ in $5 \% \mathrm{CO}_{2}$ atmosphere. The supernatant was removed and $100 \mu \mathrm{l}$ of propanol was added and the plates were gently shaken to solubilize the formed formazan. The absorbance was measured using a micro plate reader at $540 \mathrm{~nm}$. The percentage growth inhibition was calculated using the following formula and concentration of test drug needed to inhibit cell growth by $50 \%\left(\mathrm{IC}_{50}\right)$ values is generated from the doseresponse curves for each cell line. The $\%$ of cell viability reported here are found to carry a maximum of $\pm 5 \%$ deviation.

$$
\% \text { Growth Inhibition }=100-\left(\frac{\text { Mean OD of individual test group }}{\text { Mean OD of control group }} \times 100\right)
$$

\section{Results and Discussion}

\section{Synthesis of AuNPs}

AuNPs were synthesized by using aqueous leaves extract of $A$. hirsutus, which has a rich source of phytochemicals such as alkaloids, flavonoids, saponins, terpenoids etc., traditionally used as antibacterial and anti-inflammatory agent [21]. These phytochemicals acts as both reducing and capping agent for the formation of AuNPs. The formation of AuNPs was monitored using UV-Vis spectra, Fig. 1, these noble metal nanoparticles exhibit strong optical extinction coefficient at visible and near-infrared

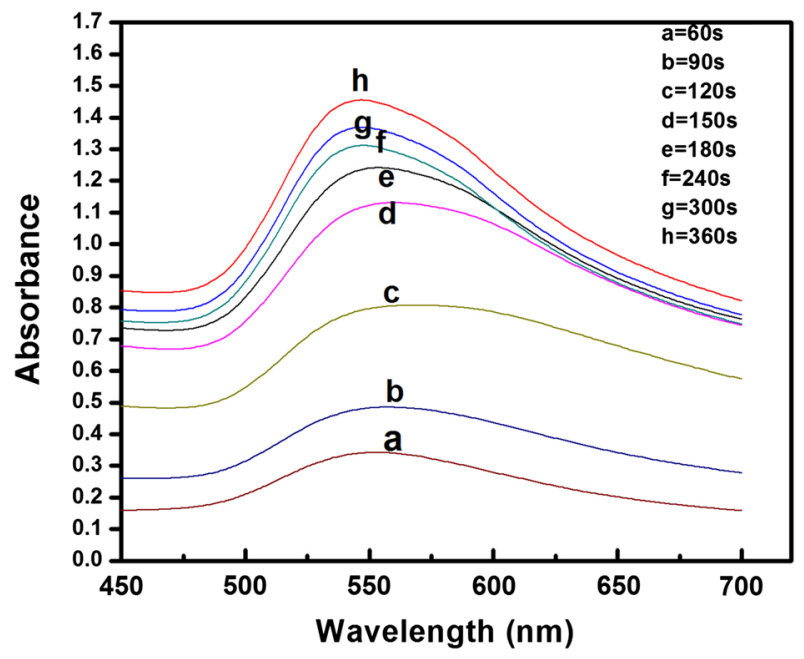

Fig. 1 UV-Vis spectra of the reaction mixture showing the SPR peak at $540 \mathrm{~nm}$ 
region due to localized surface plasmon resonance (LSPR, $\lambda_{\max }$ ) of their free electrons, upon excitation by an electromagnetic field [22, 23]. As the reaction mixture $\left(\mathrm{HAuCl}_{4}+\right.$ plant leaf extract) was irradiated at regular intervals of time in microwave oven, the color was found to change from light-yellow $(t=20 \mathrm{~s})$ to yellowish-brown $(\mathrm{t}=120 \mathrm{~s})$ and then to dark-brown $(\mathrm{t}=420 \mathrm{~s})$, indicating the formation of AuNPs. The optical density of the reaction mixture increased in response to the irradiation time observed up to $360 \mathrm{~s}$. The $\lambda_{\max }$ decreased from 550 to $540 \mathrm{~nm}$ (blue shift) is mainly due to increase in particle size [24].

Crystallite size and structure of AuNPs was examined using XRD pattern, Fig. 2a. The four distinct diffraction peaks of the $2 \theta$ values of $38.7^{\circ}, 44.3^{\circ}, 65^{\circ}$ and $77.5^{\circ}$ can be assigned to (111), (200), (220) and (311) planes respectively; indicating that the AuNPs are $f c c$ structured (JCPDS 89-3722) [25]. The crystallite mean size of AuNPs was found to be $32 \mathrm{~nm}$ using the Debye-Scherrer's equation, $\mathrm{d}=\mathrm{K} \lambda / \beta \cos \theta$ where, $\mathrm{K}$-shape factor between 0.9 and $1.1, \lambda$-incident $\mathrm{X}$-ray wavelength $(\mathrm{Cu} \mathrm{K} \alpha=0.1542 \mathrm{~nm}), \beta$-full width half maximum in radians of the prominent line (111) and $\theta$-position of that line in the pattern. The TEM image (Fig. 2b, c) shows the near spherical nature of the particles with the sizes ranging from 5 to $40 \mathrm{~nm}$. It is also clear that the nanoparticles are well separated showing no agglomeration. The SAED image (Fig. 2d) confirms the $f c c$ structure of AuNPs. Optimum efficiency of delivery of the AuNPs into the pulmonary system can be achieved for nanoparticles of diameter $\cong 40 \mathrm{~nm}$ [26].
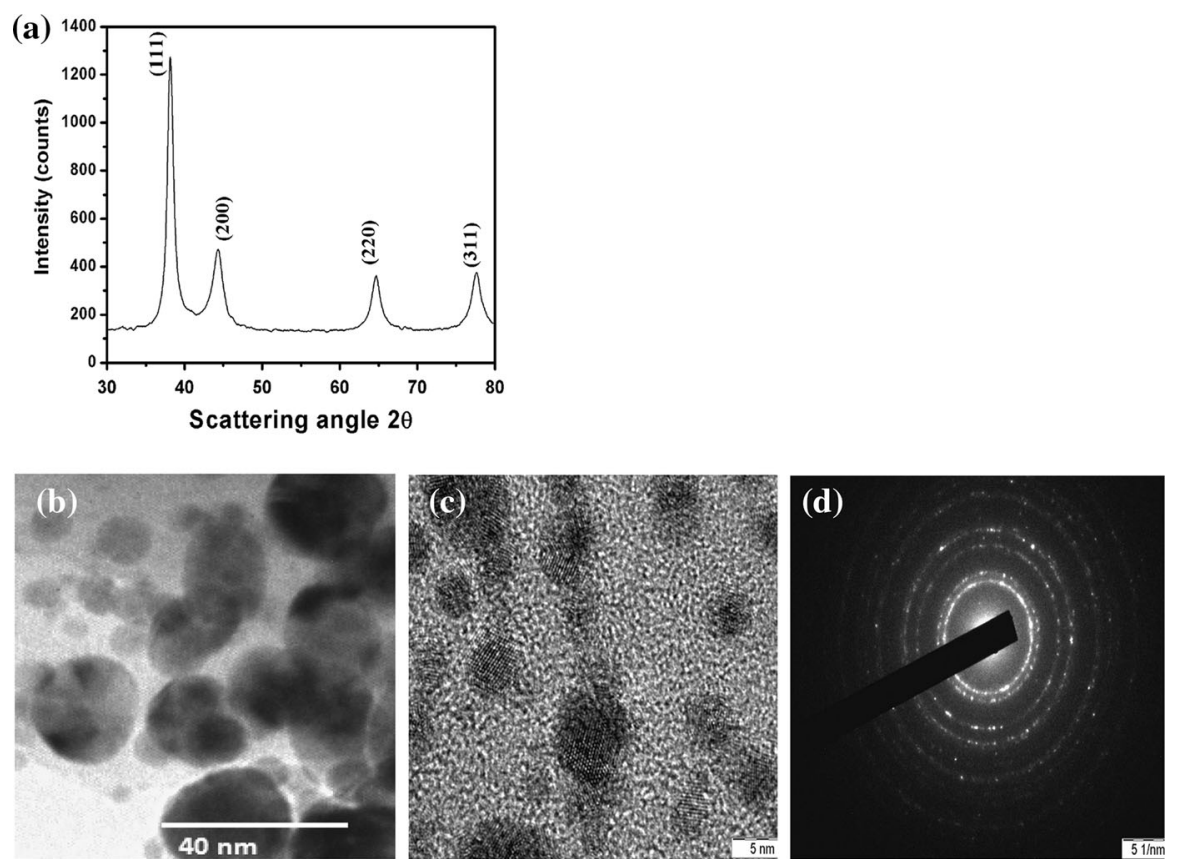

Fig. 2 a XRD pattern of AuNPs. b, c TEM images of AuNPs in different magnifications d SEAD pattern of AuNPs 


\section{Conjugation of AuNPs with Activated FA and CHL}

The UV-Vis spectra of AuNPs, activated FA, CHL and AuNPs-FA-CHL are given in Fig. 3. The SPR peaks for AuNPs $(\sim 530 \mathrm{~nm})$, activated FA $(\sim 282 \mathrm{~nm})$ and CHL $(\sim 485 \mathrm{~nm})$ can be seen clearly. For AuNPs-FA-CHL complex, the SPRs shifted to 570, 350 and $450 \mathrm{~nm}$, respectively. This is a clear indication of AuNPs conjugation with FA and CHL.

As shown in Fig. 4, the FT-IR spectra of plant extract shows the presence of polyphenols, flavonoids etc. $\mathrm{O}-\mathrm{H}$ stretching shows peak at $3431 \mathrm{~cm}^{-1}$. A peak at $2422 \mathrm{~cm}^{-1}$ corresponds to aldehydic $\mathrm{C}-\mathrm{H}$ stretching; weaker band at $1667 \mathrm{~cm}^{-1}$ is ascribed to ketone and ester group [27, 28]. The peak at $1520 \mathrm{~cm}^{-1}$ corresponds to germinal methyl group and a peak near $1120 \mathrm{~cm}^{-1}$ is assigned to $\mathrm{C}-\mathrm{N}$ stretching vibrations [29]. When we compare this with the FT-IR spectra of AuNPs synthesized by same plant extract, there is a shift in IR bands from 1667 to 1573, 1520 to 1383 and 1120 to $1250 \mathrm{~cm}^{-1}$. This indicates phytochemicals such as polyphenols, flavonoids and terpenoids are involved in reduction of $\mathrm{Au}^{3+}$ to AuNPs. The peaks at 1713 and $1645 \mathrm{~cm}^{-1}$ for activated FA correspond to $-\mathrm{COOH}$ and $-\mathrm{NH}_{2}$ stretching, respectively. The peak at $3488 \mathrm{~cm}^{-1}$ was assigned to -OH group of FA. In the case of AuNPs-FA, the absence of $1713 \mathrm{~cm}^{-1}$ is due to the interaction of carboxylic group of FA with AuNPs. The emergence of a strong peak at $1504 \mathrm{~cm}^{-1}$ corresponds to asymmetric bending vibrations of $-\mathrm{CO}$ and stretching of primary amines -NH- suggesting that the FA must be anchored to AuNPs via an amide linkage [19], Although, the FA has both $\alpha$ and $\gamma$-carboxylic acids, $\gamma$ carboxylic acid is activated preferentially due to its higher reactivity [30, 31]. The FT-IR spectra of CHL complex exhibits a prominent peak at $1702 \mathrm{~cm}^{-1}$ which corresponds to free carboxylic acids. For AuNPs-FA-CHL complex, appearance of

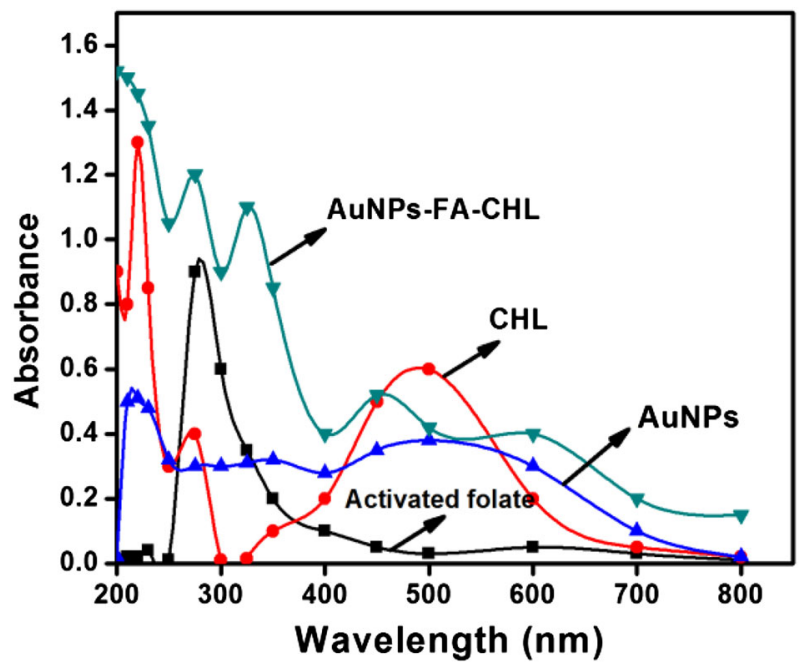

Fig. 3 UV-Vis spectra of AuNPs before and after conjugation with FA and CHL. For comparison, the spectra of activated folate and CHL are also shown 
Fig. 4 FT-IR spectra of $A$. hirsutus extract, AuNPs, activated FA, AuNPs-FA, CHL and AuNPs-FA-CHL

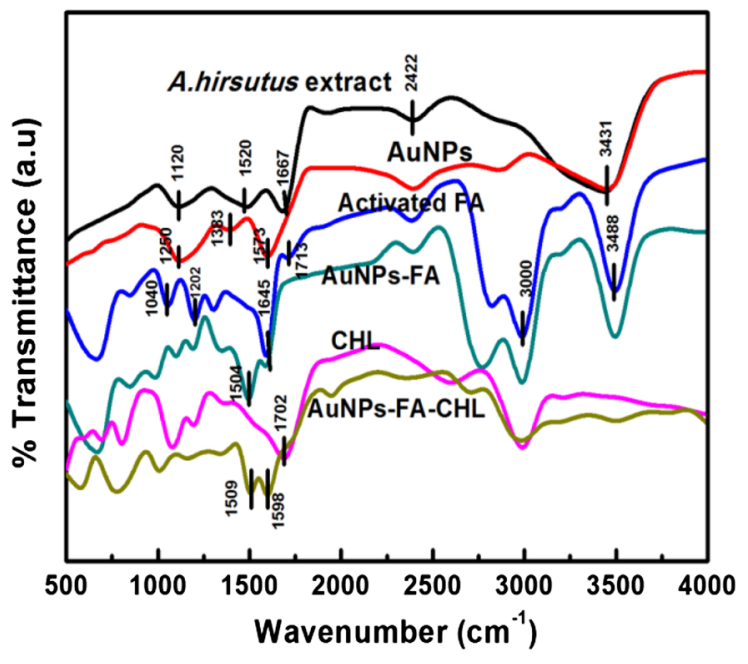

a strong peak at $1598 \mathrm{~cm}^{-1}$ corresponds to asymmetric bending vibrations of -CO and stretching of primary amines $-\mathrm{NH}-$. This indicates the interaction of AuNPsFA-CHL complex via peptide linkage [32].

The TEM images of AuNPs-FA-CHL are shown in Fig. 5. In comparison with Fig. 2b, there are no significant differences in morphology of AuNPs before and after conjugation of the drug. However, a thin coating of scum surrounded on AuNPs is clearly seen due to bio-capping of plant based molecules and conjugated FA and CHL. In fact the presence of plant phytochemicals on AuNPs enhances its antimicrobial activity and also facilitates the conjugation of anticancer drugs.
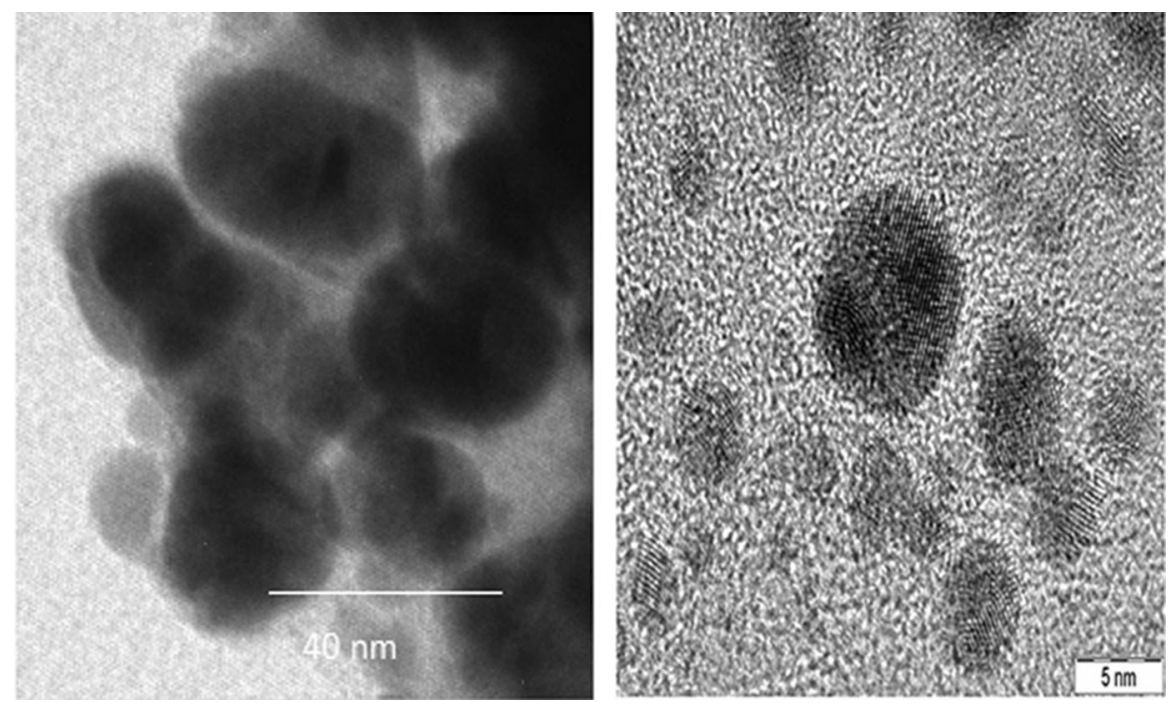

Fig. 5 TEM images of AuNPs-FA-CHL 
The cytotoxic effects of AuNPs modified with FA and CHL were tested against vero and different cell lines. The effect of AuNPs, free CHL and AuNPs-FA-CHL on vero and HeLa, RKO and A549 cells are compared in Fig. 6 at different incubation periods (24-72 h) as a function of different dose levels. It can be observed that $\%$ viability of cells decreases with increasing dose i.e., 50-250 $\mu \mathrm{g} / \mathrm{ml}$ and increasing incubation period $24-72 \mathrm{~h}$. Further, at lower concentration $(50 \mu \mathrm{g} / \mathrm{ml})$ the percentage of cell viability of AuNPs is found to be $~ 80 \%$ for both normal and cancer cells. Though, a steady decrease in the viability of cells with increasing concentration of AuNPs is also observed. At higher dose of $250 \mu \mathrm{g} / \mathrm{ml}$, the viability of vero, HeLa,
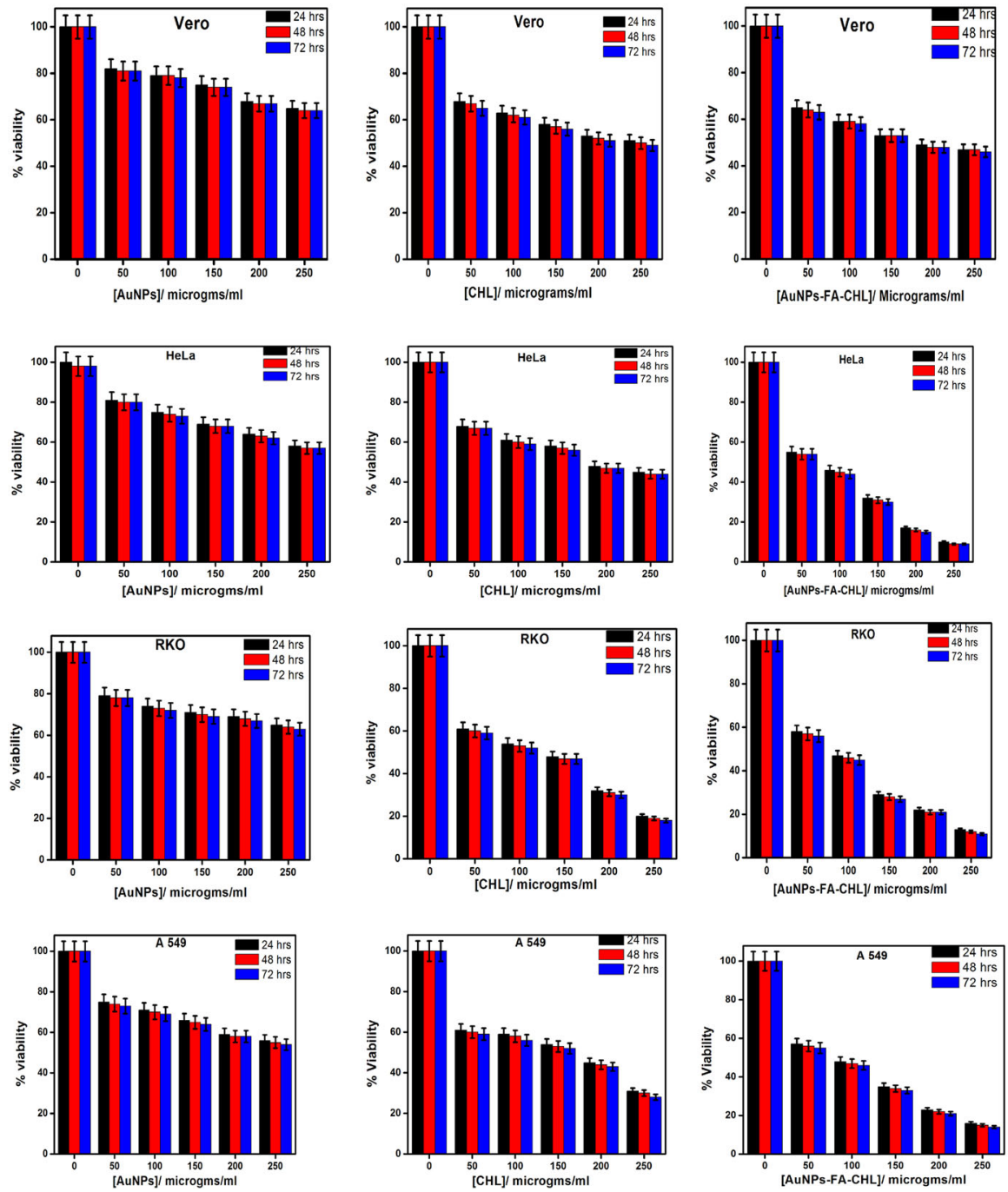

Fig. 6 Cytotoxicity of AuNPs, CHL and AuNPs-FA-CHL on different cancer cell lines as a function of dose levels. (The F values, $\mathrm{P}$ values and d.f are shown in Tables 2, 3, and 4) 
Table 1 Growth-inhibitory effect of AuNPs-FA-CHL after $48 \mathrm{~h}$

\begin{tabular}{lllll}
\hline Samples & \multicolumn{4}{l}{ Inhibitory effect on cell lines $\left(\mathrm{IC}_{50}\right)$} \\
\cline { 2 - 5 } & Vero & HeLa & RKO & A-549 \\
\hline AuNPs & $220 \mu \mathrm{g} / \mathrm{ml}(50.06 \%)$ & $210 \mu \mathrm{g} / \mathrm{ml}(53.70 \%)$ & $210 \mu \mathrm{g} / \mathrm{ml}(52.50 \%)$ & $205 \mu \mathrm{g} / \mathrm{ml}(51.70 \%)$ \\
CHL & $180 \mu \mathrm{g} / \mathrm{ml}(48.75 \%)$ & $150 \mu \mathrm{g} / \mathrm{ml}(54.55 \%)$ & $155 \mu \mathrm{g} / \mathrm{ml}(53.60 \%)$ & $158 \mu \mathrm{g} / \mathrm{ml}(54.22 \%)$ \\
AuNPs- & $170 \mu \mathrm{g} / \mathrm{ml}(47.25 \%)$ & $130 \mu \mathrm{g} / \mathrm{ml}(58.60 \%)$ & $132 \mu \mathrm{g} / \mathrm{ml}(58.32 \%)$ & $133 \mu \mathrm{g} / \mathrm{ml}(58.32 \%)$ \\
FA- & & & & \\
CHL & & & \\
\hline
\end{tabular}

RKO and A549 cells dropped to 68.8, 58.2, 61.1, and $58.5 \%$ respectively after $72 \mathrm{~h}$ of treatment. The $\mathrm{IC}_{50}$ values and \% inhibition of cell proliferation of AuNPs is given in Table 1. This high cytotoxicity of AuNPs on human cancer cells depends on biocapped organic moiety and morphology of nanoparticles [33]. Cancer cells (as compared to vero cells) carries disordered endothelial cells because of which, there will be more accumulation of nanoparticles at tumor site, which can easily penetrate inside the cancer cells leading to high cytotoxic effect as compared to the normal vero cells [34]. On the other hand vero cells showed good biocompatibility towards AuNPs; mainly due to the presence of cell growth boosting factors of the extract from A. hirsutus, which carries high concentration of biomolecules such as polyphenols, terpenoids, alkaloids etc. [21,35]. It means there is a preferential targeting of cancer cells by these bioconjugated AuNPs.

Further, we have tested the cytotoxic effect of CHL and AuNPs-FA-CHL on normal and cancer cells and it was found to be considerably high at all the concentrations (50-250 $\mu \mathrm{g} / \mathrm{ml})$. For instance; at higher dose of $250 \mu \mathrm{g} / \mathrm{ml} \mathrm{CHL}$, the cell viability is found to be $\sim 50 \%$ for normal cells and $\sim 32 \%$ for cancer cells. The $\mathrm{IC}_{50}$ values of CHL are found to be, $180 \mu \mathrm{g} / \mathrm{ml}$ for vero, $150 \mu \mathrm{g} / \mathrm{ml}$ for HeLa, $155 \mu \mathrm{g} / \mathrm{ml}$ for RKO, and $158 \mu \mathrm{g} / \mathrm{ml}$ for A549 cell lines, upon $48 \mathrm{~h}$ exposures. These results signify $\mathrm{CHL}$ as one of the potent chemotherapeutic drug. Comparing cytotoxic effect of AuNPs-FA-CHL with CHL and AuNPs alone, the toxicity effect of AuNPs-FA-CHL complex was found to be very high. The cell viability was found to be $\sim 50 \%$ for normal cells, $\sim 20 \%$ for cancer cells at $200 \mu \mathrm{g} / \mathrm{ml}$ concentration and $\sim 10 \%$ for cancer cells at $250 \mu \mathrm{g} / \mathrm{ml}$ concentration of AuNPsFA-CHL. A sudden decrease in the percentage of viability of cells at higher concentration was observed. The $\mathrm{IC}_{50}$ value of AuNPs-FA-CHL on normal and cancer cells was found to be 170 and $130 \mu \mathrm{g} / \mathrm{ml}$ respectively. Thus, AuNPs-FACHL is highly potent when compared to CHL or AuNPs alone; even at lower concentrations. The CHL-tethered nanoparticles demonstrated a significantly better cytotoxicity, than CHL alone; on all cell lines and relatively biocompatibility for normal cells; probably due to, the impact of potential targeting on cancer cells. Good number of researches has also explored similar biocompatibility of AuNPs $[36,37]$. However, the cytotoxicity of AuNPs on cancer cells mainly depends on their size and shape of nanoparticles, as well as on the type of drug [38, 39].

Brown et al. [40] have reported conjugating anticancer drug oxaliplatin to AuNPs for improved drug delivery. And this complex shows high cytotoxicity towards lung 
Table 2 Average \% viability of different cell lines against various concentration of AuNPs

\begin{tabular}{llllll}
\hline \begin{tabular}{l} 
Concentration of $\begin{array}{l}\text { Cancer cell lines/AuNPs } \\
\text { AuNPs in } \mu \mathrm{g}\end{array}$ \\
\cline { 2 - 5 }
\end{tabular} & $\begin{array}{l}\text { Vero/AuNPs } \\
\text { Avg. \% viability }\end{array}$ & $\begin{array}{l}\text { Hela/AuNPs } \\
\text { Avg. \% viability }\end{array}$ & $\begin{array}{l}\text { RKO/AuNPs } \\
\text { Avg. \% viability }\end{array}$ & $\begin{array}{l}\text { A-549/AuNPs } \\
\text { Avg. \% viability }\end{array}$ & $\begin{array}{l}\text { Sum of } \\
\text { rows }\end{array}$ \\
\hline 50 & 80.33 & 79.33 & 78.33 & 74.00 & 312.00 \\
100 & 78.67 & 73.00 & 71.00 & 69.00 & 291.67 \\
150 & 77.33 & 69.33 & 69.00 & 67.00 & 282.67 \\
200 & 68.33 & 62.00 & 68.00 & 59.33 & 257.67 \\
250 & 66.33 & 59.33 & 56.00 & 57.00 & 238.67 \\
Sum of columns & 371.00 & 343.00 & 342.33 & 326.33 & \\
\hline
\end{tabular}

(a) Summary values of variances

\section{Total SS}

SS between column treatment

(b) The ANNOVA table (two way ANNOVA)

\begin{tabular}{lrrrrrr}
\hline Source of variance & \multicolumn{1}{l}{ SS } & d.f & MS & F ratio & $\begin{array}{l}5 \% \mathrm{~F} \text { limit } \\
\text { (or the table values }\end{array}$ & Result \\
\hline Between columns & 206.76 & $(4-1)=3$ & 68.92 & 14.75 & $\mathrm{~F}(3,12)=3.49$ & $\mathrm{H}_{0}$ rejected \\
Between rows & 828.59 & $(5-1)=4$ & 207.15 & 44.33 & $\mathrm{~F}(4,12)=3.26$ & $\mathrm{H}_{0}$ rejected \\
Residual or error & 56.08 & $3 * 4=12$ & 4.67 & & &
\end{tabular}

Source Primary data, data recorded at different time periods i.e. 24,48 and $72 \mathrm{~h}$ and the average $\%$ age viability data is used for the purpose of analysis

epithelial cancer cell line A549 and on colon cancer cell lines HCT116, RKO. Dong N Heo et al. [41] in their study described AuNPs surface-functionalized with PEG, biotin, paclitaxel (PTX), which can be useful as a theranostic agent for cancer therapy against cancer cells such as HeLa and MG63. However, the detailed studies are required to understand the process of endocytosis and molecular mechanism of nanoparticles on cancer cells.

Jaganathan et al. [42] in their study synthesized silver nanoparticles (EW-AgNP) using Eudrilus eugeniae earthworms as reducing and stabilizing agents. The synthesized nanoparticles were characterized using UV-vis spectrophotometer, FTIR and FESEM. The cytotoxicity of EW-AgNP were tested against HepG2 cells by MTT assay, which showed decreased cell proliferation rate (in dose dependent manner). It also exhibited impending toxicity on Plasmodium parasites and mosquito vectors.

Kadarkarai Murugan et al. [43] biofabricated silver nanoparticles (AgNP) using plant extract of Azadirachta indica as reducing and stabilizing agent. AgNP were then characterized using UV-vis spectrophotometry, SEM, EDX, XRD and FTIR spectroscopy. The AgNP was found to be toxic against Anopheles stephensi larvae and pupae; $\mathrm{LC}_{50}$ of $\mathrm{AgNP}$ is found to be 3.9 ppm (larva I), which is very less when 
Table 3 Average \% viability of different cell lines against various concentration of CHL

\begin{tabular}{llllll}
\hline $\begin{array}{l}\text { Concentration } \\
\text { of CHL in } \mu \mathrm{g}\end{array}$ & \multicolumn{2}{l}{ Cancer cell lines/CHL } & & \\
\cline { 2 - 5 } & $\begin{array}{l}\text { Vero/CHL } \\
\text { Avg. \% viability }\end{array}$ & $\begin{array}{l}\text { Hela/CHL } \\
\text { Avg. \% viability }\end{array}$ & $\begin{array}{l}\text { RKO/CHL } \\
\text { Avg. \% viability }\end{array}$ & $\begin{array}{l}\text { A-549/CHL } \\
\text { Avg. \% viability }\end{array}$ & $\begin{array}{l}\text { Sum of } \\
\text { rows }\end{array}$ \\
\hline 50 & 66.67 & 67.33 & 59.00 & 59.00 & 252.00 \\
100 & 62.00 & 59.00 & 51.00 & 58.00 & 230.00 \\
150 & 58.00 & 57.00 & 47.00 & 52.00 & 214.00 \\
200 & 52.00 & 49.33 & 31.00 & 44.00 & 176.33 \\
250 & 49.00 & 43.33 & 19.00 & 32.00 & 143.33 \\
Sum of columns & 287.67 & 276.00 & 207.00 & 245.00 & \\
\hline
\end{tabular}

(a) Summary values of variances

\section{Total SS}

SS between column treatment

SS between row treatment

(b) The ANNOVA table (two way ANNOVA)

\begin{tabular}{lrlrlll}
\hline Source of variance & \multicolumn{1}{l}{ SS } & d.f & MS & F ratio & $\begin{array}{l}5 \% \mathrm{~F} \text { limit } \\
\text { (or the table values }\end{array}$ & Result \\
\hline Between columns & 781.48 & $(4-1)=3$ & 260.49 & 14.62 & $\mathrm{~F}(3,12)=3.49$ & $\mathrm{H}_{0}$ rejected \\
Between rows & 1880.53 & $(5-1)=4$ & 470.13 & 26.38 & $\mathrm{~F}(4,12)=3.26$ & $\mathrm{H}_{0}$ rejected \\
Residual or error & 213.82 & $3 * 4=12$ & 17.82 & & &
\end{tabular}

Source Primary data, data recorded at different time periods i.e. 24,48 and $72 \mathrm{~h}$ and the average $\%$ age viability data is used for the purpose of analysis

compared to that of plant extract $232.8 \mathrm{ppm}$ (larva I). And In vitro, AgNP is also found to be toxic to chloroquine-resistant Plasmodium falciparum parasites.

Giovanni Benelli et al. [44] in their study exhibit the relationship between cancer and mosquito-born diseases, with special reference to malaria. The study hypothesized that; Anopheles vectors may transmit obscure viruses linked with cancer development. Further, many studies have explored the probability of the hamster reticulum cell sarcoma being transmitted through the bites of Aedes aegypti which transforms healthy cells into tumor cells. These studies have found that Mosquito bites may influence human metabolic pathways following different mechanisms, leading to other viral infections and/oncogenesis.

Testing the hypothesis; using ANOVA the following results are observed;

From Table 2a, b; the variance reported in terms of \% age viability among different cell lines and at different concentration of AuNPs in $\mu \mathrm{g}$ is statistically significant; as the derived value of $\mathrm{F}$ is greater than $\mathrm{F}$ statistical values derived at $5 \%$ level of significance and $\mathrm{H}_{0}$ is rejected.

From Table $3 \mathrm{a}, \mathrm{b}$; the variance reported in terms of $\%$ age viability among different cell lines and at different concentration of CHL in $\mu \mathrm{g}$ is statistically 
Table 4 Average \% viability of different cell lines against various concentration of AuNPs-FA-CHL

\begin{tabular}{|c|c|c|c|c|c|}
\hline \multirow{2}{*}{$\begin{array}{l}\text { Concentration of } \\
\text { AuNPs-FA- } \\
\text { CHL } \\
\text { in } \mu \mathrm{g}\end{array}$} & \multicolumn{4}{|c|}{ Cancer cell lines/AuNPs-FA-CHL } & \multirow[b]{2}{*}{$\begin{array}{l}\text { Sum of } \\
\text { rows }\end{array}$} \\
\hline & $\begin{array}{l}\text { Vero/AuNPs- } \\
\text { FA-CHL } \\
\text { Avg. \% viability }\end{array}$ & $\begin{array}{l}\text { Hela/AuNPs- } \\
\text { FA-CHL } \\
\text { Avg. \% viability }\end{array}$ & $\begin{array}{l}\text { RKO/AuNPs- } \\
\text { FA-CHL } \\
\text { Avg. \% viability }\end{array}$ & $\begin{array}{l}\text { A-549/AuNPs- } \\
\text { FA-CHL } \\
\text { Avg. \% viability }\end{array}$ & \\
\hline 50 & 64.00 & 53.33 & 57.00 & 56.00 & 230.33 \\
\hline 100 & 59.67 & 44.00 & 47.00 & 48.00 & 198.67 \\
\hline 150 & 52.00 & 29.00 & 29.00 & 36.00 & 146.00 \\
\hline 200 & 48.67 & 18.00 & 21.33 & 20.00 & 108.00 \\
\hline 250 & 45.33 & 9.33 & 15.00 & 19.00 & 88.67 \\
\hline Sum of columns & 269.67 & 153.67 & 169.33 & 179.00 & 771.67 \\
\hline
\end{tabular}

(a) Summary values of variances

\begin{tabular}{lr}
\hline Total SS & 5518.86 \\
SS between column treatment & 1636.19 \\
SS between row treatment & 3567.44 \\
SS residual or error & 315.22 \\
\hline
\end{tabular}

(b) The ANNOVA table (two way ANNOVA)

\begin{tabular}{lrlrlll}
\hline Source of variance & SS & d.f & MS & F ratio & $\begin{array}{l}5 \% \text { F limit } \\
\text { (or the table values }\end{array}$ & Result \\
\hline Between columns & 1636.19 & $(4-1)=3$ & 545.40 & 20.76 & $\mathrm{~F}(3,12)=3.49$ & $\mathrm{H}_{0}$ rejected \\
Between rows & 3567.44 & $(5-1)=4$ & 891.86 & 33.95 & $\mathrm{~F}(4,12)=3.26$ & $\mathrm{H}_{0}$ rejected \\
Residual or error & 315.22 & $3 * 4=12$ & 26.27 & & & \\
\hline
\end{tabular}

Source Primary data, data recorded at different time periods i.e. 24, 48 and $72 \mathrm{~h}$ and the average $\%$ age viability data is used for the purpose of analysis

significant; as the derived value of $\mathrm{F}$ is greater than $\mathrm{F}$ statistical values derived at $5 \%$ level of significance and $\mathrm{H}_{0}$ is rejected.

From Table $4 \mathrm{a}, \mathrm{b}$; the variance reported in terms of $\%$ age viability among different cell lines and at different concentration of AuNPs-FA-CHL in $\mu \mathrm{g}$ is statistically significant; as the derived value of $\mathrm{F}$ is greater than $\mathrm{F}$ statistical values derived at $5 \%$ level of significance and $\mathrm{H}_{0}$ is rejected.

The most important function of AuNPs-FA-CHL is; the controlled release of drug in an ideal tumor environment. In this study, (Fig. 7) we have tested the drug release profile; at different conditions, $\mathrm{pH} 7.2$ (physiological $\mathrm{pH}$ ) and $5.4(\mathrm{pH}$ of the tumor environment). The rate of drug release was found to be fast at $\mathrm{pH} 5.4$ and relatively slower at $\mathrm{pH} 6.7$ and $\mathrm{pH}$ 7.2. This type of mechanism is said to act as a dual pronged tool; for treatment of cancer. Immediately, after the injection of the AuNPs-FACHL conjugate; it is found to first interact with blood components, at physiological $\mathrm{pH}$ (7.2). At this $\mathrm{pH}$, the amount of drug release is relatively slow (most of CHL remains anchored at the surface of AuNPs). Once these conjugates, enter into the cancer cells via an endocytic pathway; the amount of drug release will significantly 
Fig. 7 Drug release profile of AuNPs-FA-CHL with time at different $\mathrm{pH}$

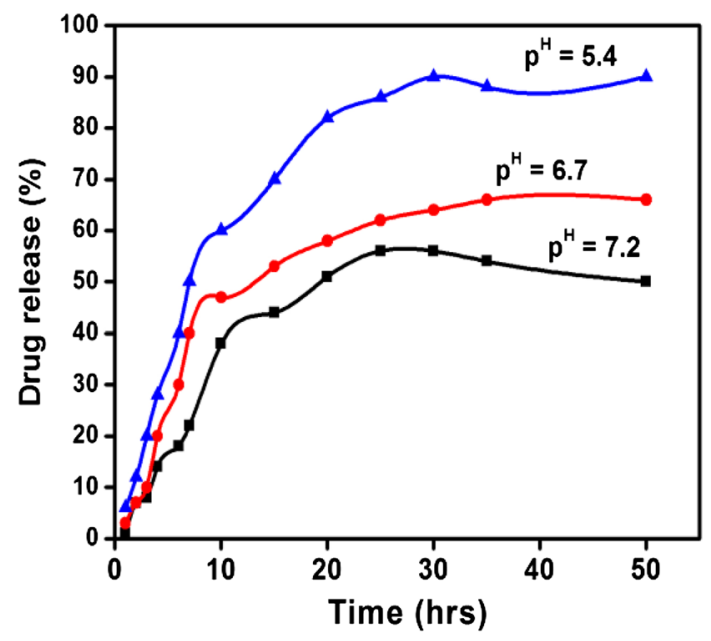

increases (the majority tumor environments have been found to be acidic $\mathrm{pH} 4.5-6.5$ ) depending on the nature of tumor. In an ideal tumor environment, the delivery of drug from nano-vehicles is mainly dependent on its $\mathrm{pH}$.

\section{Conclusion}

A spherical shaped AuNPs have been successfully synthesized by using A. hirsutus leaves extract as a bioreducing agent. These AuNPs were found to be coated/ adsorbed with biomolecules from plant extract, and such a bio-capping was helpful for further conjugation with drug. Activated FA and CHL were effectively conjugated to AuNPs forming AuNPs-FA-CHL. Such a drug delivery complex, AuNPs-FA-CHL is tested here against normal epithelial cells and human cancer cells (HeLa, RKO and A549); which when compared to AuNPs and CHL alone, the drug conjugated AuNPs has shown a high toxicity towards human cancer cells by significantly decreasing the percentage viability of cells. At the same time, it shows high toxicity towards HeLa cell lines compared to other cell lines. Further the amount of drug released has found to be maximum at $\mathrm{pH} 5.3$ ( $\mathrm{pH}$ of an ideal tumor environment). In summary, we have developed an eco-friendly, bio-compatible drug delivery complex. Further studies (in vivo) are required to understand the exact mechanism of action of drug on cancer cells.

\section{References}

1. M. O. Abdel, M. B. Hadeel, E. A. Sameer, A. D. Zoheir, and F. E. Mohamed (2012). Cancer Cell Int. 12, 1.

2. F. Jacques, D. S. Coralie, Y. Nouara, T. Jean, S. Kevin, C. Henri, and G. Nicolas (2014). ACS Chem. Neurosci. 5, 216. 
3. P. C. Chen, C. M. Sandra, and K. O. Adegboyega (2008). Nanotechnol. Sci. Appl. 1, 45.

4. R. K. O'Reilly (2007). Phil. Trans. R. Soc. A 365, 2863.

5. A. F. Robert (2005). Nanomed. Nanotechnol. 1, 2.

6. S. K. Sahoo, S. Parveen, and J. J. Panda (2007). Nanomedicine 3, 20.

7. P. Dan, M. K. Jeffrey, H. Seungpyo, C. F. Omid, M. Rimona, and L. Robert (2007). Nature Nanotechnol. 2, 751.

8. C. Laura, B. Luisa, G. Felisa, A. M. Jesús, and B. Antonio (2010). Chem. Eng. J. 164, 92.

9. D. Raghunandan, B. Ravishankar, G. Sharanabasava, D. R. Mahesh, V. Harsoor, M. S. Yatagatti, M. Bhagawanraju, and A. Venkataraman (2011). Cancer Nanotechnol. 2, 57.

10. D. S. Balaji, S. Basavaraja, D. Raghunandan, D. B. Mahesh, K. P. Belawadi, and V. Abbaraju (2008). Sci. Technol. Adv. Mater. 9, 1.

11. J. Hongje, R. Soo-Ryoon, K. Kostas, W. H. Sang, and M. Dal-Hee (2013). Biomaterials 34, 3503.

12. T. Ciprian, S. Olga, O. Anamaria, D. Mircea, P. Bobe, M. Ofelia, S. Sergiu, F. Adrian, P. Emoke, A. Mihaela, K. Gabriel, C. Victor, B. N. Ioana, and I. Alexandru (2012). J. Gastrointest. Liver Dis. 21, 187.

13. D. G. Jacob, P. K. Bishnu, and R. Z. Eugene (2007). J. Am. Chem. Soc. 129, 11653.

14. D. A. Marco, I. E. Keith, and B. Shankar (2014). J. Am. Chem. Soc. 136, 5860.

15. B. A. Kamen and A. Capdevila (1986). Proc. Natl. Acad. Sci. 83, 5983.

16. B. Fadeel and A. E. Bennett (2010). Adv. Drug Deliv. Rev. 62, 362.

17. G. Steinberg and R. F. Borch (2001). J. Med. Chem. 44, 69.

18. Y. Rui, S. Wang, P. S. Low, and D. H. Thompson (1998). J. Am. Chem. Soc. 120, 11213.

19. P. Sunil, O. Goldie, M. Ashmi, S. Ritu, T. Mukeshchand, and S. Madhuri (2013). J. Mater. Chem. B 1, 1361.

20. U. Chiara, B. Daniele, L. Giada, H. Iris, P. Christine, B. Giovanni, E. U. Ronald, and K. James (2009). Part. Fiber Toxicol. 6, 1.

21. M. G. Madhura, K. Islam, and M. G. Sushama (1998). Biochim. et Biophys. Acta 1381, 256.

22. M. Paul (1996). Langmuir 12, 788.

23. L. Stephan and A. E. Mostafa (1999). J. Phys. Chem. B 103, 4212.

24. S. Yallappa, J. Manjanna, M. A. Sindhe, N. D. Satyanarayan, S. N. Pramod, and K. Nagaraja (2013). Spectrochim. Acta A 110, 108.

25. T. Y. Suman, S. R. Radhika, R. Ramkumar, C. Rajthilak, and P. Perumal (2014). Spectrochim. Acta A 118, 11.

26. S. Jain, D. G. Hirst, and J. M. Sullivan (2012). Br. J. Radiol. 85, 101.

27. T. Bhuvaneswari, M. Thiyagarajan, N. Geetha, and P. Venkatachalam (2014). Acta Trop. $135,55$.

28. T. Y. Suman, D. Elumalai, P. K. Kaleena, and R. S. R. Radhika (2013). Ind. Crops Prod. 47, 239.

29. Y. S. Jae, K. J. Hyeon, and S. K. Beom (2009). Process Biochem. 44, 1133.

30. J. Bingbing, B. B. John, and L. Bingyun (2009). Nanotechnol. Sci. Appl. 2, 21.

31. K. Mohamed, W. Y. Meng, H. Eliza, M. Dusica, and S. Ursula (2015). Thno 5, 357.

32. M. Ashmi, P. Sunil, T. Mukeshchand, J. Dhanashree, and S. Madhuri (2014). J. Mater. Chem. B 2, 698.

33. K. Gopinath, K. S. Venkatesh, R. Ilangovan, K. Sankaranarayanan, and A. Arumugam (2013). Ind. Crops Prod. 50, 737.

34. C. D. Erik, A. M. Megan, H. Xiaohua, K. Bin, and A. E. Mustafa (2011). Chem. Soc. Rev. 40, 3391.

35. A. D. Mubarak, N. Thajuddin, K. Jeganathan, and M. Gunasekaran (2011). Colloids Surf. B 85, 360.

36. M. Aradhana, K. Madhuree, P. Shipra, C. Vasvi, K. C. Gupta, and C. S. Nautiyal (2014). Bioresour. Technol. 166, 235.

37. B. N. Kannan and S. Natarajan (2010). Mater. Charact. 61, 1232.

38. C. Jingyi, S. Fusayo, J. W. Benjamin, H. Cang, J. C. Michael, Y. L. Zhi, A. Leslie, Z. Hui, B. K. Michael, L. Xingde, and X. Younan (2005). Nano Lett. 5, 473.

39. M. F. Jesus, C. B. Catherine, O. R. Mathis, and S. G. C. Adam (2006). Langmuir 22, 3286.

40. D. B. Sarah, N. Paola, S. Jo-Ann, S. David, R. E. Paul, V. Balaji, J. F. David, A. P. Jane, G. Duncan, and J. W. Nial (2010). J. Am. Chem. Soc. 132, 4678.

41. N. H. Dong, H. Y. Dae, M. Ho-Jin, B. L. Jung, S. B. Min, C. L. Sang, J. L. Won, S. In-Cheol, and K. Keun (2012). Biomaterials 33, 856.

42. A. Jaganathan, K. Murugan, C. Panneerselvam, P. Madhiyazhagan, D. Dinesh, C. Vadivalagan, A. T. Aziz, B. Chandramohan, U. Suresh, R. Rajaganesh, J. Subramaniam, M. Nicoletti, A. Higuchi, A. A. Alarfaj, M. A. Munusamy, S. Kumar, and G. Benelli (2016). Parasitol. Int. 65, (3), 276. 
43. K. Murugana, C. Panneerselvamb, C. M. Samidossa, P. Madhiyazhagana, U. Suresha, M. Ronia, B. Chandramohana, J. Subramaniama, D. Dinesha, R. Rajaganesha, M. Paulpandia, H. Weic, A. T. Azizb, M. S. Alsalhid, S. Devanesand, M. Nicolettie, R. Pavelaf, and A. Canaleg (2016). Res. Vet. Sci. 106, 14.

44. G. Benelli, A. L. Iacono, A. Canale, and H. Mehlhorn (2016). Parasitol. Res. 115, 2131. 